\title{
PENGARUH MODEL PEMBELAJARAN SAINS TEKNOLOGI MASYARAKAT DAN MODEL PROJECT BASED LEARNING TERHADAP HASIL BELAJAR FISIKA DAN SIKAP ILMIAH SISWA
}

\author{
Diah Eka Pratiwi' ${ }^{1}$ Feriansyah Sesunan ${ }^{2}$, I Dewa Putu Nyeneng ${ }^{3}$ \\ ${ }^{1,2,3}$ FKIP Universitas Lampung, Jl. Prof. Dr. Soemantri Brodjonegoro No. 1; \\ diahekapratiwi71@gmail.com
}

\begin{abstract}
Influence Science Technology Society Models and Project Based Learning Models of the Physics Learning Outcomes and Scientific Attitude. Many students who consider physics are difficult and abstract lessons because of ignorance application of the concept of physics. This research aims to knowing there is an influence science technology society models and project based learning models of the physics learning outcomes and scientific attitude or not. This research was conducted at SMAN 3 Bandarlampung using Pretest-Posttest Control Group Design with control class (X IPA $A_{4}$ given treatment model of PjBL and experimental class (X IPA $A_{5}$ given treatment model of STM. Based on the results of data analysis, found that there is a positive and significant influence STM models to student learning outcomes and scientific attitudes while the model of PjBL only affect to student learning outcomes. The results of data analysis also show that students who study with the STM models gain higher learning outcomes and scientificl attitudes than study with the PjBL models.
\end{abstract}

Keywords: STM Models, PjBL Models, Learning Outcomes, Scientific Attitudes.

\begin{abstract}
Abstrak: Pengaruh Model Pembelajaran Sains Teknologi Masyarakat dan Model Project Based Learning terhadap Hasil Belajar Fisika dan Sikap ilmiah Siswa. Banyak siswa yang menganggap pelajaran fisika adalah pelajaran yang sulit dan abstrak karena ketidaktahuan dari penerapan konsep fisika. Penelitian ini bertujuan untuk mengetahui ada atau tidaknya pengaruh model Sains Teknologi Masyarakat dan model Project Based Learning terhadap hasil belajar dan sikap ilmiah siswa pada materi gerak melingkar beraturan. Penelitian dilakukan di SMAN 3 Bandarlampung menggunakan desain penelitian Pretest-Posttest Control Group Design dengan kelas kontrol ( $\left.\mathrm{X} \mathrm{IPA}_{4}\right)$ diberikan treatment model PjBL dan kelas eksperimen (X IPA5) diberikan treatment model STM. Berdasarkan hasil analisis data, diperoleh bahwa terdapat pengaruh positif dan signifikan model STM terhadap hasil belajar dan sikap ilmiah siswa sedangkan model PjBL hanya berpengaruh pada hasil belajar siswa. Hasil analisis data juga menunjukkan bahwa siswa yang belajar dengan model STM memperoleh hasil belajar dan sikap ilmiah yang lebih tinggi daripada belajar dengan model $P j B L$.
\end{abstract}

Kata Kunci: Model STM, Model PjBL, Hasil Belajar, Sikap Ilmiah. 


\section{PENDAHULUAN}

Di era globalisasi ini, tuntutan kebutuhan manusia akan teknologi semakin meningkat. Kita mengetahui bahwa pengetahuan dan keteramplan (softskill) didapat dari pendidikan. Hal tersebut sesuai dengan UU No. 20 Tahun 2003 tentang sistem pendidikan nasional, pendidikan adalah suatu cara untuk mengembangkan potensi dan bakat yang dimiliki seseorang sehingga dapat menyiapkan SDM yang berkualitas dan dapat bersaing di era globalisasi ini. Berdasarkan Peraturan Pemerintah Nomor 32 Tahun 2013 tentang Standar Nasional Pendidikan menyatakan bahwa Standar Nasional Pendidikan disempurnakan secara terencana, terarah, dan berkelanjutan sesuai dengan tuntutan perubahan kehidupan lokal, nasional, dan global. Oleh karena itu, pendidikan Indonesia disusun berdasarkan kurikulum yang dapat mengimbangi akan tuntutan kehidupan.

Pembelajaran di sekolah dasar dan menengah sebagian besar masih didominasi oleh model pembelajaran ekspositori yaitu guru menerangkan dan siswa mendengarkan (Setiadi dkk, 2014). Hal tersebut sesuai dengan hasil observasi di SMA Negeri 3 Bandarlampung bahwa selama pembelajaran guru menerapkan model konvensional yaitu model ekspositori yang dirasa siswa tidak menyenangkan dan cenderung membuat bosan. Selain itu, tidak sedikit siswa yang merasa kebingungan akan penerapan konsep fisika dalam kehidupan sehari-hari. Akibatnya, pelajaran fisika hanya dianggap sebagai pelajaran dengan sekumpulan rumus-rumus yang banyak dan sulit dipahami dimana rumus- rumus tersebut dirasa tidak berguna dalam kehidupan sehari-hari siswa. Seharusnya siswa paham akan penerapan konsep-konsep fisika karena fisika adalah salah satu cabang ilmu pengetahuan alam yang sangat dekat dengan kehidupan siswa. Pelajaran fisika mempelajari aspek mendasar alam seperti berbagai peristiwa alam meliputi segala akibat dan dampak terhadap kehidupan. Fakta-fakta yang berkaitan dengan pelajaran fisika sangat dekat dengan kehidupan siswa yang dengan mudah dapat membentuk sebuah konsepnya sendiri sehingga dalam belajar, siswa memiliki pengetahuan awal yang harus dibangun dan dikembangkannya (Paul dalam Sardiman, 2011: 38). Konsep pengetahuan yang dibentuk secara mandiri akan tahan lebih lama dalam ingatan siswa. Selain itu, jarang sekali guru memberikan permasalahan yang ada untuk dipecahkan bersama oleh siswa secara ilmiah. Oleh karna itu, aktifitas pembelajaran hanya menitik beratkan pada kemampuan berpikir pada tingkat mengingat, menghafal, dan sedikit memahami (Merta dalam Setiadi dkk, 2014). Permasalahan-permasalahan yang muncul di lapangan tersebut, ternyata mempengaruhi sikap ilmiah siswa yang rendah dan kemudian berdampak pada hasil belajar siswa yang rendah pula. Sikap ilmiah terwujud dari hasil belajar yang merupakan puncak kegiatan pendidikan khususnya pembelajaran (Dimyati dan Mudjiono, 2009: 3).

Selain aspek kognitif, aspek sikap juga perlu diperhatikan sesuai dengan kurikulum 2013 yang menyataan kurikulum yang diterapkan 
menekankan pada pengembangan karakter siswa disamping menuntut aspek kognitif dimana salah satunya adalah adalah sikap ilmiah.

Fakta di lapangan tidak berjalan sesuai dengan yang diharapkan. Banyak masalah-masalah yang muncul seperti hasil belajar siswa yang rendah dan cara mengajar guru yang kurang menarik saat dilakukan observsi awal. Salah satu upaya untuk mengatasi pembelajaran yang sulit dipahami dan meningkatkan ketertarikan siswa dalam mempelajari fisika adalah menggunakan model pembelajaran Sains Teknologi Masyarakat (STM). Hal tersebut didukung oleh penelitian dari Supriyanto dan Kholida (2016) yang mengemukakan bahwa terdapat pengaruh model STM terhadap peningkatan hasil belajar siswa. Lestari, dkk (2016) menambahkan bahwa pengaruh model STM terhadap peningkatan hasil belajar siswa sebesar 22,58\%. Model Pembelajaran Sains Teknologi Masyarakat (STM) adalah model pembelajaran yang mengaitkan materi pelajaran fisika dengan kenyataan yang ada dalam kehidupan sehari-hari. Selama proses pembelajaran, model STM mengaitkan isu-isu yang ada dimasyarakat atau luar kelas ke dalam proses belajar-mengajar, sehingga siswa dapat memahami secara menyeluruh (Poedjiadi, 2010: 84). Melalui model STM, memberikan harapan untuk menciptakan manusia yang berkualitas dan peka terhadap masalah-masalah yang timbul di masyarakat.

Selain model STM, menurut Alawiyah, dkk (2015) dan Mustikaningrum (2015), terdapat model $P j B L$ yang memiliki harapan untuk me- ningkatkan hasil belajar dan sikap ilmiah siswa. Model PjBL dan model STM merupakan salah satu bagian dari pembelajaran Contextual Teaching and Learning $(C T L)$ yang berpotensi untuk meningkatkan hasil belajar dan sikap ilmiah siswa karena dalam proses pembelajarannya mengaitkan antara materi yang diajarkan dengan dunia nyata (Depdiknas, 2002).

Adapun tujuan dari penelitian ini adalah untuk mengetahui pengaruh model pembelajaran STM dan PjBL terhadap hasil belajar dan sikap ilmiah siswa. Berdasarkan pemaparan masalah di atas, maka dilakukanlah penelitian yang berjudul "Pengaruh Model Sains Teknologi Masyarakat dan Model Project Based Learning terhadap Hasil Belajar dan Sikap Ilmiah Siswa".

\section{METODE}

Penelitian ini merupakan penelitian eksperimen dengan desain penelitian menggunakan PretestPosttest Control Group Design. Desain penelitian dapat dilihat pada Gambar 1.

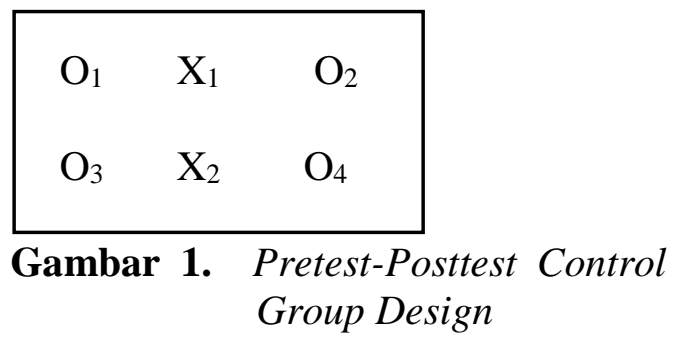

Desain penelitian menggunakan dua kelas, yaitu kelas eksperimen dan kelas kontrol. Sebelum pembelajaran, diberikan pretest dan setelah mengikuti pembelajaran, diberikan posttest. Pada kelas ekperimen diterapkan model pembelajaran STM sedangkan pada 
kelas kontrol diterapkan model Project Based Learning (PjBL).

Populasi penelitian ini adalah siswa kelas X IPA SMA Negeri 3 Bandarlampung pada semester ganjil tahun pelajaran 2017/2018 yang terdiri dari enam kelas dengan jumlah 203 siswa sedangkan sampel penelitian yang diambil adalah kelas $\mathrm{X} \mathrm{IPA}_{4}$ dan kelas X IPA5 dengan jumlah 74 siswa menggunakan teknik random sampling (sampel acak).

Variabel penelitian ini terdiri dari variabel bebas dan variabel terikat. Variabel bebas adalah model STM dan model PjBL sedangkan variabel terikatnya adalah hasil belajar dan sikap ilmiah siswa.

Pengumpulan data dilakukan dengan menggunakan tes hasil belajar yang terdiri dari 15 soal pilihan jamak dan angket sikap ilmiah yang terdiri dari 18 butir pernyataan yang mengacu pada pengelompokkan sikap ilmiah berdasarkan American Association for Advancement of Science (AAAS) dan Harlen dalam Kusuma (2013: 9). Instrumen yang telah diuji validitas dan reliabilitas tersebut, diberikan sebagai pretest dan posttest pada kelas eksperimen dan kelas kontrol.

Data yang diperoleh, selanjutnya dilakukan analisis data dan uji hipotesis untuk mengetahui apakah hipotesis tersebut diterima atau ditolak. Untuk menganalisis tes hasil belajar, digunakan skor pretest dan posttest yang telah melalui uji normalitas, homogenitas dan uji hipotesis menggunaka uji paired sample t-test. Pada analisis data angket sikap ilmiah, dilakukan uji normalitas yang kemudian dilanjutkan uji wilcoxon.

\section{HASIL DAN PEMBAHASAN}

Penelitian mengenai pengaruh model pembelajaran STM dan $P j B L$ terhadap sikap ilmiah ini dilakukan di SMA Negeri 3 Bandarlampung pada materi gerak melingkar beraturan. Penelitian ini dilakukan sejak tanggal 9 November 2017 hingga 24 Novem-ber 2017 sesuai jadwal pelajaran fisika di sekolah. Proses pembelajaran berlangsung selama tiga kali tatap muka dengan alokasi waktu 3 x 45 menit tiap kali tatap muka.

Penelitian ini dilaksanakan pada kelas X IPA5 sebagai kelas eksperimen dan kelas X IPA4 sebagai kelas kontrol. Pada kelas eksperimen di-terapkan model STM dengan tahapan pembelajaran yaitu invitasi/apersepsi/ eksplorasi terhadap siswa, pembentukan konsep, aplikasi konsep dalam kehidupan, pemantapan konsep, dan penilaian sedangkan pada kelas kontrol diterapkan model $P j B L$ pada 31 siswa sebagai kelas kontrol dengan tahapan pembelajaran pada model $P j B L$ ini yaitu penentuan proyek, perancangan langkah-langkah pe nyelesaian proyek, penyusunan jadwal, penyelesaian proyek dengan fasilitas dan memonitoring, penyusunan laporan dan hasil presentasi hasil proyek, evaluasi proses dan hasil proyek. Sebelum dan sesudah pembelajaran diberikan tes berupa pretest dan posttest. Instrumen yang diujikan telah diuji dan dinyatakan valid dan reliabel. Tabel 1 dan Tabel 2 berikut menyajikan hasil belajar dan hasil uji normalitas data pada kelas eksperimen dan kelas kontrol. 
Tabel 1 menunjukkan nilai rata-rata pretest kelas $P j B L$ lebih tinggi daripada kelas STM tetapi setelah diberikan perlakuan, nilai posttest kelas STM memperoleh lebih tinggi daripada kelas $P j B L$. Hal ini menyebabkan nilai $N$ gain atau nilai selisih antara pretest dan posttest pada kelas STM lebih tinggi daripada kelas $P j B L$. Secara langsung, kita belum bisa mengetahui apakah terdapat pengaruh signifikan setelah diterapkan kedua model pembelajaran terhadap hasil belajar dan sikap ilmiah siswa. Oleh sebab itu, perlu dilakukan uji statistik guna mengetahui apakah terdapat pengaruh secara signifikan atau tidak.
Tabel 2 menyajikan uji statistik pada skor pretest dan posttest di kelas STM dan PjBL berdistribusi normal. Data yang berdistribusi normal, selanjutnya dilakukan uji homogenitas untuk memeriksa apakah data memiliki varians yang sama (homogen). Jika data berdistribusi normal dan homogen, selanjutnya dilakukan uji paired sample t-test. Uji paired sample t-test di-gunakan untuk menguji adanya perbedaan antara nilai pretest dan posttest setelah diterapkan model pembelajaran. Jika terdapat perbedaan, maka dapat dikatakan suatu model pembelajaran yang diterapkan berpengaruh terhadap hasil belajar.

Tabel 1. Data Hasil Belajar Kognitif Siswa

\begin{tabular}{lcc}
\hline \multicolumn{1}{c}{ Jenis Nilai } & STM & $\boldsymbol{P j B L}$ \\
\hline Rata-rata Nilai Pretest & 34.45 & 36.74 \\
Rata-rata Nilai Posttest & 83.45 & 71.96 \\
Rata-rata Nilai N-gain & 0.75 & 0.56 \\
\hline
\end{tabular}

Tabel 2. Hasil Uji Normalitas Shapiro-wilk

\begin{tabular}{cccc}
\hline Kelas & Hasil & Sig. & Kesimpulan \\
\hline \multirow{3}{*}{ STM } & Pretest & 0.064 & $\mathrm{H}_{0}$ diterima \\
\cline { 2 - 4 } & Posttest & 0.082 & $\mathrm{H}_{0}$ diterima \\
\cline { 2 - 4 } & $\boldsymbol{N}$-gain & 0.910 & $\mathrm{H}_{0}$ diterima \\
\hline \multirow{3}{*}{ PjBL } & Pretest & 0.105 & $\mathrm{H}_{0}$ diterima \\
\cline { 2 - 4 } & Posttest & 0.063 & $\mathrm{H}_{0}$ diterima \\
\cline { 2 - 4 } & $\boldsymbol{N}$-gain & 0.227 & $\mathrm{H}_{0}$ diterima \\
\hline
\end{tabular}

Tabel 3. Hasil Uji Homogenitas

\begin{tabular}{ccccc}
\hline Test & $\begin{array}{c}\text { Levene } \\
\text { Statistic }\end{array}$ & Sig. & Kesimpulan & Keterangan \\
\hline Pretest & 2.861 & 0.096 & $\mathrm{H}_{0}$ diterima & Homogen \\
\hline Posttest & 3.328 & 0.073 & $\mathrm{H}_{0}$ diterima & Homogen \\
\hline
\end{tabular}

Tabel 4. Hasil Uji Paired Sample t-test

\begin{tabular}{ccc}
\hline Kelas & Sig.(2-tailed) & Kesimpulan \\
\hline STM & 0.000 & $\mathrm{H}_{0}$ ditolak \\
\hline$P j B L$ & 0.000 & $\mathrm{H}_{0}$ ditolak \\
\hline
\end{tabular}


Tabel 3 menunjukkan bahwa data homogen yang selanjutnya dapat dilakukan uji paired sample t-test. Hasil uji paired sample t-test dapat dilihat pada Tabel 4 yang dapat disimpulkan bahwa terdapat perbedaan rata-rata hasil pretest-posttest yang menggunakan model pembelajaran STM dan model PjBL. Hal tersebut berarti bahwa terdapat pengaruh model STM dan model PjBL terhadap hasil belajar fisika siswa. Hal tersebut sejalan dengan penelitian yang dilakukan Supriyanto dan Kholida (2016) serta Lestari, dkk. (2016) yang menyetujui bahwa terdapat pengaruh model pembelajaran STM terhadap hasil belajar fisika siswa. Selain itu, pernyataan model $P j B L$ berpengaruh terhadap hasil belajar siswa didukung oleh penelitian yang di-lakukan oleh Alawiyah, dkk. (2015) dan Mustikaningrum (2015).
Kedua model tersebut ternyata berpengaruh terhadap hasil belajar fisika siswa, namun jika dilihat dari nilai $\quad N$-gain, maka nilai $N$-gain kelas STM lebih tinggi dari pada kelas $P j B L$ yang dapat dilihat pada Gambar 2, artinya peningkatan belajar pada kelas STM lebih tinggi dibandingkan dengan kelas $P j B L$. Untuk meningkatkan hasil belajar fisika yang lebih tinggi, maka pembelajaran dengan model STM lebih unggul daripada model PjBL.

Selanjutnya dilakukan analisis data dan uji hipotesis pada sikap ilmiah. Hal pertama yang dilakukan yaitu uji normalitas pada pretest dan posttest kelas eksperimen dan kelas kontrol. Tabel 5 dan Tabel 6 berikut menyajikan data sikap ilmiah dan uji normalitasnya.

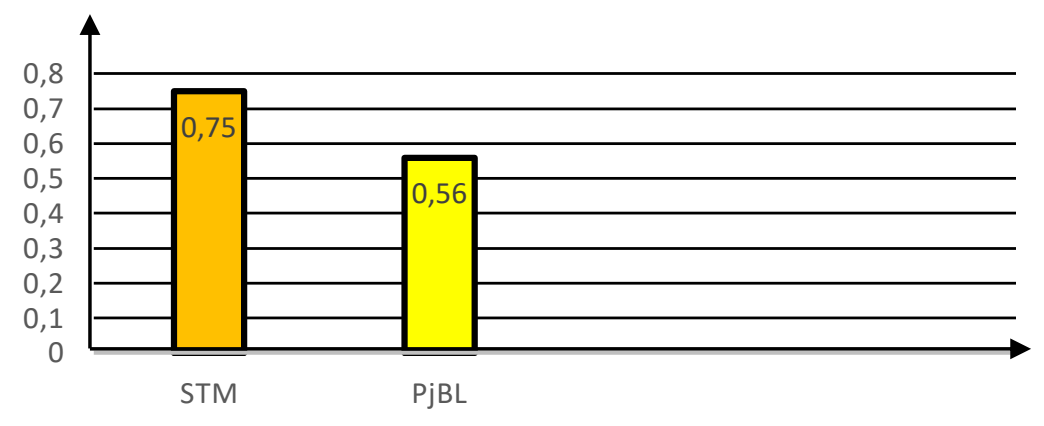

Gambar 2 Grafik Perbandingan nilai $N$-gain 
Tabel 5. Data Rata-rata Sikap ilmiah Siswa

\begin{tabular}{lcc}
\hline \multicolumn{1}{c}{ Jenis Nilai } & STM & $\boldsymbol{P j B L}$ \\
\hline Rata-rata Nilai Pretest & 2.63 & 2.60 \\
Rata-rata Nilai Posttest & 3.05 & 2.93 \\
Rata-rata Nilai $N$-gain & 0.0043 & 0.0033 \\
\hline
\end{tabular}

Tabel 6. Hasil Uji Normalitas Sikap ilmiah Siswa

\begin{tabular}{|c|c|c|c|}
\hline \multirow[t]{2}{*}{ Kelas } & \multirow{2}{*}{ Hasil } & Shapiro-wilk & \multirow{2}{*}{ Kesimpulan } \\
\hline & & $\begin{array}{c}\text { Sig. } \\
0.000\end{array}$ & \\
\hline STM & Posttest & 0.397 & $\mathrm{H}_{0}$ diterima \\
\hline \multirow{2}{*}{$P j B L$} & Pretest & 0.000 & $\mathrm{H}_{0}$ ditolak \\
\hline & Posttest & 0.397 & $\mathrm{H}_{0}$ diterima \\
\hline
\end{tabular}

Tabel 7. Hasil Uji Wilcoxon

\begin{tabular}{ccc}
\hline Kelas & Asymp. Sig (2-tailed) & Kesimpulan \\
\hline STM & 0.001 & $\mathrm{H}_{0}$ ditolak \\
\hline$P j B L$ & 0.304 & $\mathrm{H}_{0}$ diterima \\
\hline
\end{tabular}

Tabel 5 menunjukkan bahwa nilai rata-rata pretest, posttest, dan $\mathrm{N}$-gain siswa kelas STM lebih tinggi daripada kelas PjBL. Selanjutnya, Tabel 6 menunjukkan kesimpulan bahwa skor pretest dan posttest siswa berdistribusi tidak normal. Jika datanya berdistribusi tidak normal, maka selanjutnya harus menggunakan uji nonparametrik yaitu, uji wilcoxon yang disajikan pada Tabel 7. Tabel 7 menyimpulkan bahwa $\mathrm{H}_{0}$ ditolak pada kelas STM, artinya dapat diketahui bahwa terdapat perbedaan rata-rata hasil pretest-posttest yang menggunakan model pembelajaran STM terhadap sikap ilmiah siswa. Adanya perbedaan tersebut menunjukkan bahwa terdapat pengaruh model STM terhadap sikap ilmiah siswa. Berbeda dengan model PjBL, melalui uji wilcoxon diperoleh kesimpulan $\mathrm{H}_{0}$ diterima, artinya bahwa tidak ada perbedaan rata-rata hasil pretest-posttest yang menggunakan model $P j B L$ terhadap sikap ilmiah siswa. Hal tersebut menunjukkan bahwa tidak terdapat pengaruh model $P j B L$ terhadap sikap ilmiah siswa. Secara garis besar, maka dapat disimpulkan bahwa model STM lebih unggul daripada model $P j B L$ untuk meningkatkan sikap ilmiah siswa.

Pada proses pembelajaran di kelas STM dan kelas $P j B L$ memiliki beberapa keunggulan yang sama, diantaranya dapat meningkatkan motivasi belajar, meningkatkan hasil belajar, membuat peserta didik menjadi lebih aktif, meningkatkan kolaborasi, mengembang- kan dan mempraktikkan keterampilan komunikasi, dan memberikan peng-alaman nyata dan langsung kepada peserta didik. Namun, setelah dilakukan tes berupa pretest dan 
posttest kepada siswa, peningkatan hasil belajar pada kelas eksperimen lebih tinggi dari pada hasil belajar pada kelas kontrol.

Peningkatan hasil belajar dan sikap ilmiah pada kelas eksperimen dapat terjadi karena siswa sudah mulai menunjukkan ketertarikan dan antusias-me mereka saat masalah fisika diangkat dari kehidupan nyata yang biasa mereka alami atau mereka ketahui sehari-hari. Meskipun kelas kontrol juga meng-angkat masalah fisika dalam dunia nyata, namun pada saat perancangan dan pembuatan proyek, banyak siswa yang kesulitan karena pada kelas $P j B L$ ini, siswa fokus pada produk yang dihasilkan saja, sehingga banyak siswa yang kurang memiliki rasa ingin tahu dan sikap kritis selama proses pembelajaran. Akibatnya, perolehan nilai sikap ilmiah pada kelas kontrol lebih rendah daripada kelas eksperimen. Rasa ingin tahu dan sikap kritis siswa yang rendah juga akan berpengaruh terhadap pengetahuan siswa terhadap materi fisika yang kemudian berdampak pada hasil belajar fisika yang rendah pula.

\section{SIMPULAN}

Berdasarkan temuan-temuan yang telah diuraikan sebelumnya, maka simpulan yang dapat diambil pada penelitian ini adalah (1) Terdapat pengaruh signifikan model pembelajaran Sains Teknologi Masyarakat terhadap hasil belajar siswa, (2) Terdapat pengaruh signifikan model pembelajaran Sains Teknologi Masyarakat terhadap sikap ilmiah siswa, (3) Terdapat pengaruh signifikan model Project Based Learning terhadap hasil belajar siswa, dan (4) Tidak terdapat pengaruh signifikan model Project Based Learning terhadap sikap ilmiah siswa.

Berdasarkan simpulan yang diperoleh, maka saran yang dapat dikemukakan, yaitu: (1) Guru sebaiknya menerapkan model pembelajaran Sains Teknologi Masyarakat untuk me-ningkatkan lebih tinggi hasil belajar dan sikap ilmiah siswa, dan (2) Guru harus menyampaikan tujuan dan indikator pembelajaran kepada siswa sehingga siswa mengerti apa yang diharapkan guru agar tujuan pembelajaran dapat tercapai.

\section{DAFTAR RUJUKAN}

Alawiyah, M., Sudarti, Prihandono, T. 2015. Pengaruh Model Pembelajaran Project Based Learning Berbasis

Pemanfaatan Barang Bekas terhadap Sikap Ilmiah dan Hasil Belajar Mata Pelajaran IPA di MTs Kecamatan Jenggawah. Jurnal Edukasi UNEJ. 2(1): 1-12

Dimyati dan Mudjiono. 2009. Belajar dan Pembelajaran. Jakarta: Rineka Cipta.

Depdiknas. 2002. Pendekatan Contextual (Contextual Teaching and Learning). Jakarta: Depdiknas.

Kemendikbud. 2013. Peraturan Pemerintah Nomor 32 Tahun 2013 tentang Standar Nasional Pendidikan. 
Kemenristek. 2016. Undang-Undang Nomor 20 Tahun 2003 tentang Sistem Pendidikan Nasional. Kemenristekdikti: UndangUndang Sistem Pendidikan Nasional.

Kusuma, M.D. 2013. Pengaruh Sikap Ilmiah Siswa terhadap Hasil Belajar Fisika dan Kemandirian Belajar Siswa SMA melalui Strategi Scaffolding-Koperatif. Jurnal Online FKIP Universitas Lampung. 1(2): 110.

Lestari, C., Melati, H.A., Hadi, L. 2016. Pengaruh Model Sains Teknologi Masyarakat terhadap Motivasi dan Hasil Belajar IPA di SMP. Diakses pada tanggal 13 Desember 2017 pukul 05.00 WIB pada jurnal.untan.ac.id/index.php/jp dpb/article/viewFile/14072/12 599

Mustikaningrum, Intan. 2015. Pengaruh Model Pembelajaran Project Based Learning Berbantuan Fotonovela terhadap Hasil Belajar dan Sikap Sains Siswa SMP.
Skripsi. Semarang: Universitas Negeri Semarang.

Poedjiadi, Anna. 2010. Sains Teknologi Masyarakat Model Pembelajaran Kontekstual Bermuatan Nilai. Bandung: Remaja Rosdakarya.

Sardiman A. M. 2011. Interaksi dan Motivasi Belajar Mengajar. Jakarta: Raja Grafindo Persada.

Setiadi, H.W., Dantes, N., Tika, I.N. 2014. Pengaruh Model Pembelajaran Sains Teknologi Masyarakat (STM) terhadap Hasil Belajar IPA Ditinjau dari Kemampuan Berpikir Kritis pada Siswa Kelas V SD

Muhammadiyah 2 Denpasar. Jurnal Penelitian Pascasarjana Undiksha. 1(4): 1-10.

Supriyanto dan Kholida, S.I. 2016. Pengaruh Penerapan Pendekatan Pembelajaran Sains Teknologi Masyarakat (STM) terhadap Peningkatan Hasil Belajar Siswa di SMA Hidayatun Najah.

Gravity. 2(1): 33-44 